PARADIGMA JURNAL KAJIAN BUDAYA Vol. 6 No. 2 (2016): 196-206

\title{
AKSARA-AKSARA PENYIMPAN INFORMASI DI BANTEN
}

\author{
Titik Pudjiastuti \\ Departemen Susastra Fakultas IImu Pengetahuan Budaya, Universitas Indonesia, titikpuji@yahoo.com.
}

DOI: $10.17510 /$ paradigma.v6i2.97

\begin{abstract}
Banten is one of the 34 provinces which helped to establish the Republic of Indonesia. Although it was just acknowledged as a province of Indonesia in 2000 , as a pepper producer Banten had been known around the world long before its sultanate even existed. The various written sources consist of scripts, archives, and inscriptions from various backgrounds, such as history, literature, and religion. This research found that there are several scripts used as a written medium in Banten, such as Arabic, Jawi (Malay-Arabic), Pegon (Arabic-Javanese), Hanacaraka, and Latin. From the text content point of view, it has been found that these scripts also function as an information depositor of Banten.
\end{abstract}

\section{KATA KUNCI}

Banten manuscript; alphabet; Eropa paper; sultanate of Banten.

\section{Pendahuluan}

Banten yang terletak di ujung barat Pulau Jawa merupakan salah satu dari 34 provinsi pembentuk negara Republik Indonesia. Meskipun baru diakui sebagai salah satu provinsi di Indonesia pada 2000—sebelumnya merupakan bagian dari provinsi Jawa Barat, sebenarnya Banten sebagai penghasil lada telah dikenal di dunia jauh sebelum kesultanan Banten berdiri (Chamber-Loir, 1995). Pada abad ke-16 Banten menjadi semakin termasyhur ketika Kesultanan Banten menjadi salah satu sentra perdagangan di kawasan Asia Tenggara (Heriyanti Ongkodharma Untara, 1998: 142). Pada masa itu Kesultanan Banten merupakan satusatunya kerajaan di Pulau Jawa yang mampu menghasilkan lada dan mengekspornya ke luar Nusantara (Atmosudirdjo,1984: 57). Untuk memenuhi kebutuhan pasar (permintaan lada), Banten ditunjang oleh daerah penghasil lada di Sumatra yang berada di bawah pengawasannya, yaitu Lampung, Palembang, Jambi, dan Bengkulu (Graaf dan Pigeaud, 1985: 252-3).

Selain masalah ekonomi (perdagangan Lada), Banten juga banyak menarik perhatian para peneliti kebudayan lama, di antaranya yang meneliti Banten dari segi sejarah adalah Ota (2006), Talens (1999), Hoesein Djajadingrat (1913), Colombijn (1989), dan Chijs (1881). Meneliti Banten berdasarkan sumber tulisnya yang berupa surat dan naskah kuno adalah Titik Pudjiastuti (1999, 2007, dan 2015), Voorhoeve 
(1975), Jones (1982), Drewes (1995), Gallop dan Arps (1991), Ricklefs (1976), dan Edel (1938). Mengkaji Banten dengan pendekatan arkeologis, di antaranya adalah Guillot dkk. (1990), Heriyanti Ongkodharma Untara (1998), Ismail (1983), dan Tjandrasasmita (1967). Masih banyak lagi penelitian lain yang memusatkan perhatiannya pada Banten, seperti Meijer (1890) mengkaji masalah bahasanya dan Bruinessen (1995) membicarakan masalah tasawuf yang berkembang di Banten.Meskipun kajian tentang Banten telah banyak dilakukan, masih ada hal lain yang dapat ditelaah. Pada tulisan ini saya akan membicarakan aksara yang digunakan sebagai media tulis di Banten. Dari berbagai data yang terwujud dalam naskah, dokumen (arsip), dan prasasti baik yang bersifat sejarah, sastra, maupun agama, diketahui bahwa aksara yang digunakan sebagai media tulis di Banten sangat beragam. Berikut ini adalah penjelasan mengenai ragam aksara itu.

\section{Aksara Arab}

Aksara Arab merupakan salah satu media tulis yang digunakan di Banten. Dari penelusuran data, diketahui bahwa aksara Arab tidak hanya digunakan untuk menulis naskah keagamaan Islam yang berisikan pelajaran agama, doa, dan al Quran, tetapi juga digunakan untuk menulis surat raja dan bangsawan Banten. Itu menunjukkan bahwa Banten memang merupakan kerajaan Islam yang kuat keagamaanya sehingga aksara Arab tidak hanya digunakan untuk hal-hal yang berkaitan dengan masalah keislaman tetapi juga untuk tujuan politis. Berikut ini adalah contoh penggunaan aksara Arab yang digunakan sebagai sarana komunikasi politis antara kerajaan Banten dan kerajaan Inggris, yang terdapat dalam surat Raja Banten ${ }^{1}$ yang ditujukan kepada King James 1, Raja Inggris².

Surat berukuran $31 \times 28,5 \mathrm{~cm}$, tebalnya 1 halaman dengan jumlah baris per halaman 9 . Teks surat ditulis dengan tulisan Arab berharakat di atas bahan naskah kertas eropa ${ }^{3}$. Surat itu tidak bertanggal tetapi, berdasarkan penjelasan Foster $(1943,166)$, yang menyebutkan bahwa surat ini diterima oleh Sir Henry Midleton pada 4 Oktober 1605, dapat diperkirakan bahwa ditulis sebelum bulan Oktober pada tahun yang sama. Di atas teks terdapat kepala surat yang berbunyi yā Fattah artinya "wahai dzat yang yang Maha Membuka." Isi surat, ucapan selamat atas pengangkatan Raja James 1 sebagai Raja Inggris dan terima kasih atas kiriman hadiahnya. Sebagai balasan, Raja Banten mengirimkan dua buah Faizar kepada Raja Inggris. Berikut ini petikan teksnya.

1 Nama sultan tidak disebutkan dalam surat karena pada masa itu Pengeran Abdullah Kadir yang sesungguhnya menjabat sebagai Sultan Banten masih sangat kecil; kerajaan Banten diatur oleh perwaliannya yang terdiri atas beberapa petinggi Banten, di antaranya adalah Mangkubumi.

2 Raja James 1 adalah putra Ratu Mary, ratu Scotland dan Henry Stewart. Lord Darnley James dinobatkan sebagai raja Inggris pada 1603. Sebagai Raja Inggris ia menyatukan Scotland, Inggris, Prancis dan Irlandia (Guy 1997, 2).

3 Kertas yang diimpor dari Eropa. Ciri kertas Eropa yang digunakan sebagai alas tulis surat ini adalah bunga lily dalam perisai bermahkota, dengan jarak garis tebal (chain lines) 2,8 cm dan garis tipis (laid lines) 13 garis dalam $1 \mathrm{~cm}$. Menurut Heawood (1950: 20) dalam bukunya Watermarks in paper in 18th-19th Century, kertas dengan cap seperti ini dipergunakan di Inggris pada awal abad ke-17.

4 Kata faizar belum dapat diidentifikasi, tetapi diperkirakan sebagai benda yang berat karena di dalam surat dinyatakan 2 faizar timbangannya seberat 14 binatang ternak berkaki empat. 
Yā Fattāhu

Sūrat yuhibbu Raja Banten yaji'ilā Raja Inggris wa Saqotlan wa Faransah wa Arlanda. Ya tūlu Allahau ta 'āla 'umrahu wazādati kulli yaumin daulatahu wa tāliqu kullu baladihim...

(Wahai Tuhan Yang Maha Membuka.

Surat Cinta Raja Banten kepada Raja Inggris, Scotland, Prancis, dan Irlandia. Semoga Allah memanjangkan umurnya dan menambahkan kemerdekaan kepada setiap negeri...)

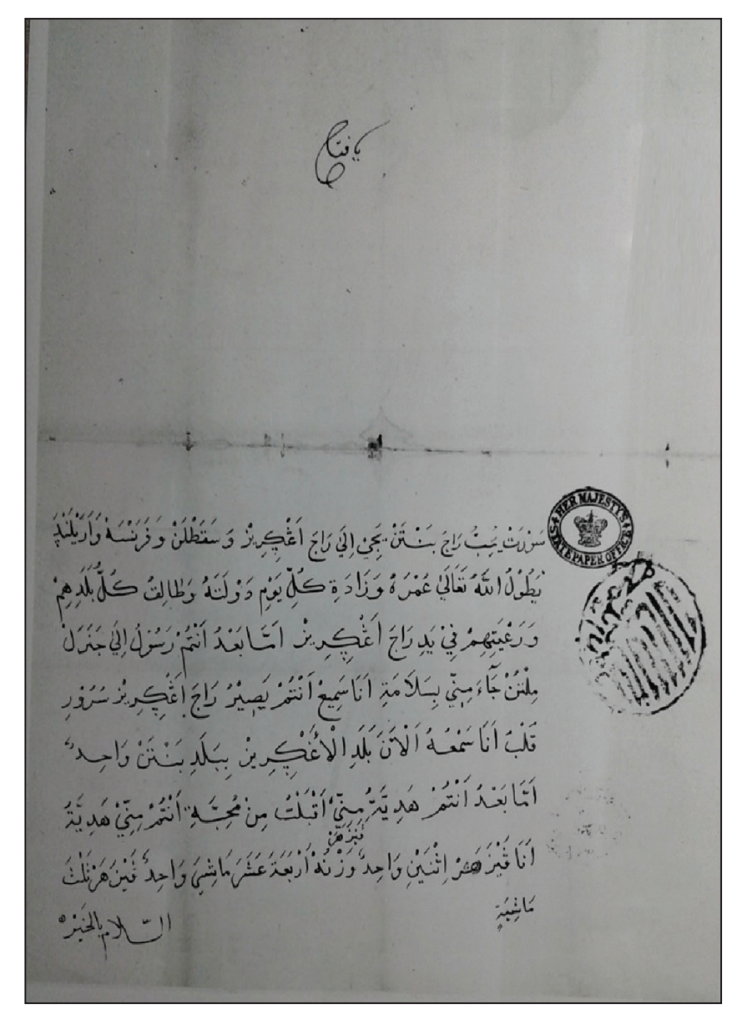

Surat Raja Banten kepada Raja Inggris, James 1, 1605.

\section{Jawi}

Aksara Jawi dikenal juga dengan istilah aksara Arab Melayu atau aksara Arab gundul. Aksara ini merupakan adopsi dari aksara Arab. Disebut Arab Melayu karena bentuk hurufnya sama dengan aksara Arab tetapi lafalnya mengikuti fonem bahasa Melayu. Jumlah huruf Jawi 34, terdiri atas 29 huruf Arab (alif - ya) dan 5

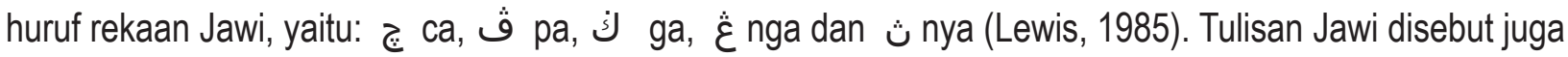
tulisan Arab gundul karena pada penulisan hurufnya tidak menerapkan harakat (tanda vokal), yaitu fathah untuk a, kasrah untuk i, dan damma untuk u. Sebagai pengganti harakat digunakan huruf saksi, yaitu huruf alif untuk bunyi a, huruf ya untuk bunyi i, dan huruf wau untuk bunyi u, sedangkan kombinasi huruf alif dan ya untuk bunyi ai (seperti: keledai), dan kombinasi huruf alif dan wau untuk bunyi au (seperti: harimau).

Berdasarkan sumber data Banten yang ada, aksara Jawi digunakan untuk menulis surat para raja atau bangsawan Banten, dokumen kolonial Belanda, dan untuk menulis teks lain. Salah satu contoh penggunaan aksara Jawi terdapat pada surat Pangeran Gebang, Bangsawan Banten yang ditujukan kepada Kapiten Moer5 pada 1619. Surat berukuran 21 x 17,5 cm ini tersimpan di Algemeen Rijks-archief (ARA) Denhaag, Belanda. Tebal naskah 1 lembar (recto-verso), berisi 3 baris sehalaman, menggunakan bahan naskah kertas 
eropa. Pada verso terdapat tulisan Latin dalam bahasa Belanda: besef van den Pangeran Gebang. Ontvg dag 07 December 1619. Berdasarkan hal ini dapat diketahui bahwa surat ditulis pada penghujung 1619.

Surat berukuran 21 x 17,5 cm ini tersimpan di Algemeen Rijks-archief (ARA) Denhaag, Belanda. Tebal naskah 1 lembar (recto-verso), berisi 3 baris sehalaman, menggunakan bahan naskah kertas eropa. Pada verso terdapat tulisan Latin dalam bahasa Belanda: besef van den Pangeran Gebang. Ontvg dag 07 December 1619. Berdasarkan hal ini diketahui bahwa surat ditulis pada penghujung 1619.

Teks ditulis dengan aksara Jawi berciri khusus, yaitu huruf fa untuk bunyi pa, dan a'in utuk lafal nga dibubuhi tiga titik di atas hurufnya, sedangkan huruf to untuk bunyi tha dibubuhi tiga titik di bawah hurufnya. Adapun kaf untuk lafal ga dan dal untuk bunyi dha dibubuhi satu titik di bawah hurufnya. Penggunaan huruf to dan dal bertitik di bawah hurufnya dikenal dalam abjad Pegon untuk membunyikan lafal tha dan dha dalam abjad huruf Jawa. Itu menunjukkan bahwa penulis surat adalah penutur bahasa dan berbudaya Jawa.

Isi surat singkat tersebut berisi pemberitahuan kepada Kapten Jan Pieterzoon Coen mengenai nama ketiga orang suruhannya. Berikut ini petikan teksnya.

// Surat Pangeran Gebang dhatang padha Kapiten Mur adha suruhan/Pangeran namanya si Anom si Kalithuh si Bladong punakawan/ dan jikalau Kapiten suka kita minta padha Kapiten Mur/l

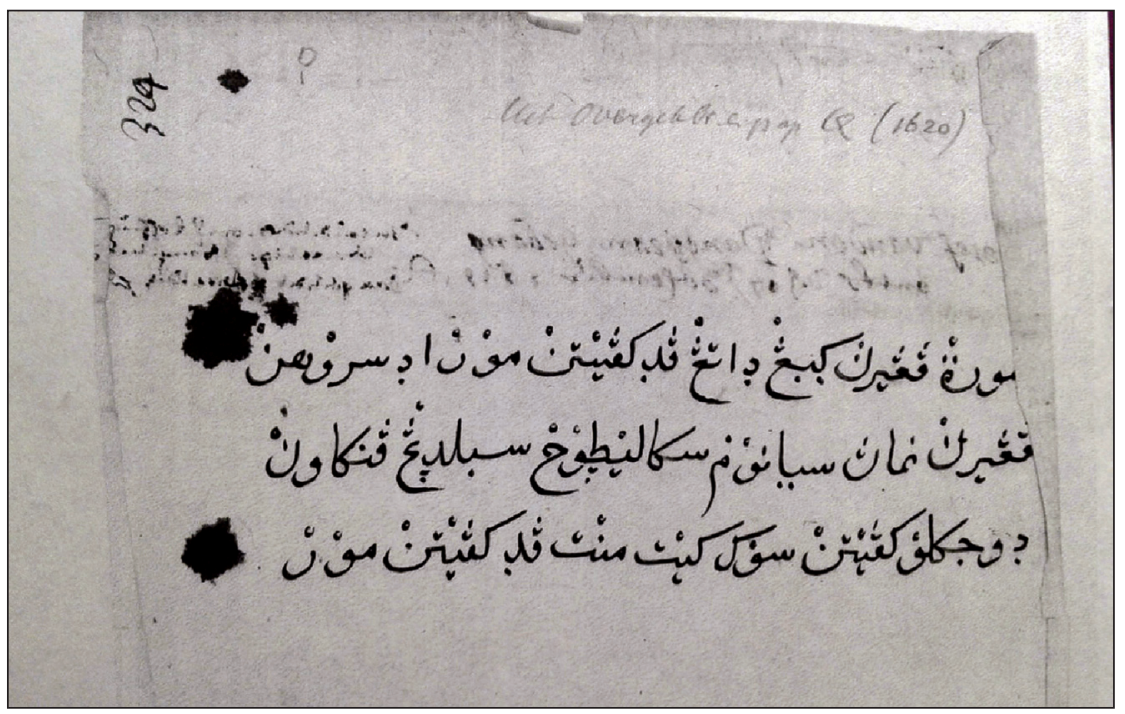

Surat Pangeran Gebang, kepada pada Jan Pieterzoon Coen, tahun 1619.

\section{Pegon}

Istilah Pegon dikenal di tanah Pasundan dan Jawa sebagai adopsi aksara Arab yang digunakan untuk sarana tulis dan penyampaian ide oleh masyarakat penggunanya. Sebagai aksara Arab adopsi, bentuk huruf Pegon sama dengan aksara Arab, tetapi mempunyai beberapa huruf rekaan yang mewakili lafal bahasa Jawa dan Sunda yang bentuk dan bunyinya meniru aksara rekaan Jawi. Oleh karena itu, aksara Pegon disebut juga aksara Arab Jawa atau aksara Arab Sunda. Di sini hanya akan dibicarakan huruf Pegon sebagai aksara Arab Jawa.

Seperti namanya, aksara Arab Jawa, huruf Pegon yang digunakan untuk menulis teks Jawa jumlah hurufnya sama dengan jumlah huruf dalam abjad Jawa, yaitu 20 huruf yang terdiri atas: ha na ca ra ka da ta sa wa la pa dha ja ya nya ma ga ba tha nga. Dari ke-20 huruf ini, huruf yang berasal dari abjad Arab 
hanya 13, yaitu: ha, nun (na), ra, kaf (ka), dal (da), ta, sin (sa), wau (wa), lam (la), jim (ja), ya, mim (ma), dan ba. Lima lainnya, ca, pa, nya, ga, dan nga, merupakan huruf rekaan Jawi, dan dua lagi, yaitu dha dan tha merupakan huruf rekaan Pegon. Dikatakan demikian karena huruf dha dan tha, yang berasal dari huruf Arab dal dan to, bertitik satu atau lebih di bawah hurufnya hanya dikenal dalam abjad Pegon Jawa.

Pada umumnya aksara Pegon Jawa ditulis dengan menerapkan harakat. Ada enam tanda vokal pada penulisan huruf Pegon yang tiga di antaranya diadopsi dari sistem penulisan huruf Arab, yaitu fathah untuk bunyi a, kasra untuk bunyi i, wau untuk bunyi u. tiga tanda vokal lain, yakni kombinasi huruf alif dan ya untuk bunyi é dan é, kombinasi huruf alif dan wau untuk bunyi o, dan tanda gelombang di atas huruf untuk penanda huruf ê pepet.

Dari penelusuran berbagai sumber tulis Banten yang menggunakan askara Pegon sebagai sarananya, diketahui bahwa aksara Pegon digunakan untuk menulis berbagai macam keperluan: teks sastra, surat, dan lain sebagainya yang berkenaan dengan agama Islam. Aksara Pegon yang digunakan untuk menulis teks keagamaan Islam di Banten pada umumnya tidak berharakat dan disebut oleh masyarakat setempat pegon gundhil, artinya tidak berambut. Itu terjadi, menurut Pigeaud (1967: 25), karena orang Banten sudah sangat menguasai berbagai idiom keagamaan Islam, jadi harakat tidak diperlukan lagi. Berikut ini adalah contoh tulisan Pegon gundil dan Pegon berharakat yang ditemukan di Banten.

Salah satu contoh naskah yang menggunakan aksara Pegon gundhil sebagai sarana tulis, teksnya adalah naskah Kitab Ajaran Islam yang ditulis di atas kertas dluwang, terdiri atas 27 baris. Berikut petikan teksnya.

//'alamate buku iki nalikane/ tinulis ing dina arba'a tanggal ping / "8" wulan Jumadilakhir tahunne hijrah 1190// 1190)

(ingatan: buku ini ketika /ditulis pada hari Rabu tanggal /8 bulan Jumadilakhir tahun Hijriah

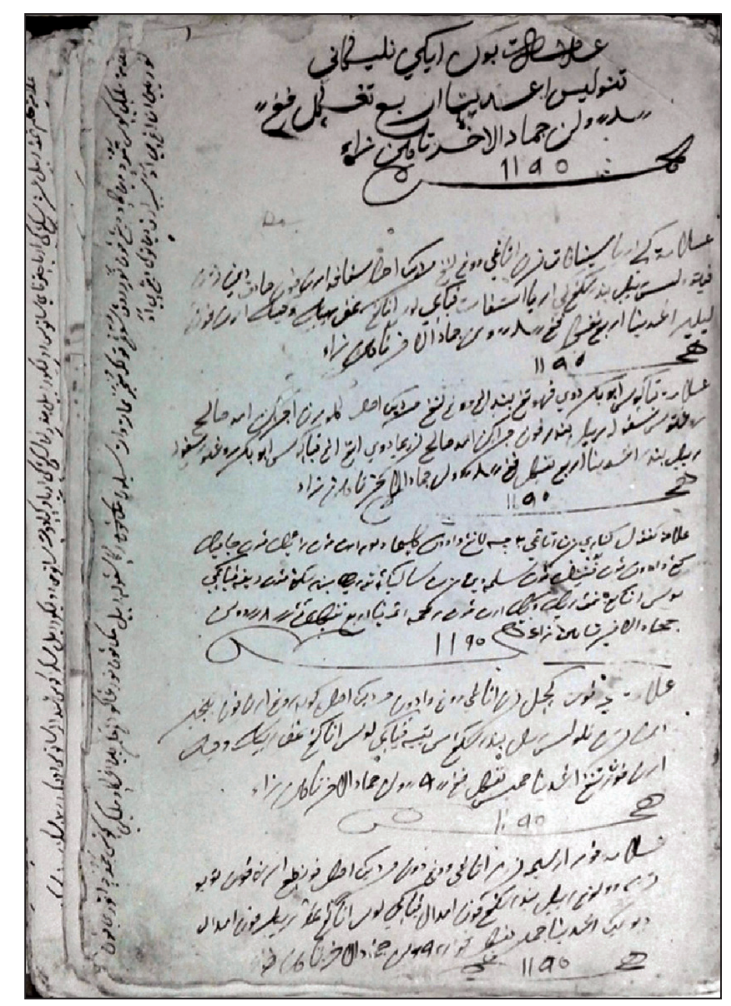

Aksara Pegon gundhil pada naskah Kitab Ajaran Islam. 
Adapun contoh penulisan aksara Pegon berharakat, ditemukan pada naskah yang berjudul Sadjarah Banten, koleksi Perpustakaan Universitas Leiden, nomor LOr. $7387^{6}$. Naskahnya berukuran $34 \times 21 \mathrm{~cm}$, tebal 510 halaman dengan jumlah baris per halaman 13 ini teksnya disusun dalam tembang macapat ${ }^{7}, 66$ pupuh. Berikut petikan teksnya.

//pupuh sinom//

//wus ginangga apaesan, ki sandikirana singgih maring ki/sastrasandine anata purwa rahayu, pepeg ingkang para sanak, yen tan / miyosa sawiji, tan kawilang, ki sandi nata kirana./

(Tembang Sinom)

(sudah berhadapan-hadapan, Ki Sandikirana dengan Ki /Sastrasandi saling memberi salam, lengkap semua sanak saudara jika/ ada salah satu yang tidak hadir, (Ki Sandi) tidak memberi pelajaran, Ki Sandi memandang.)

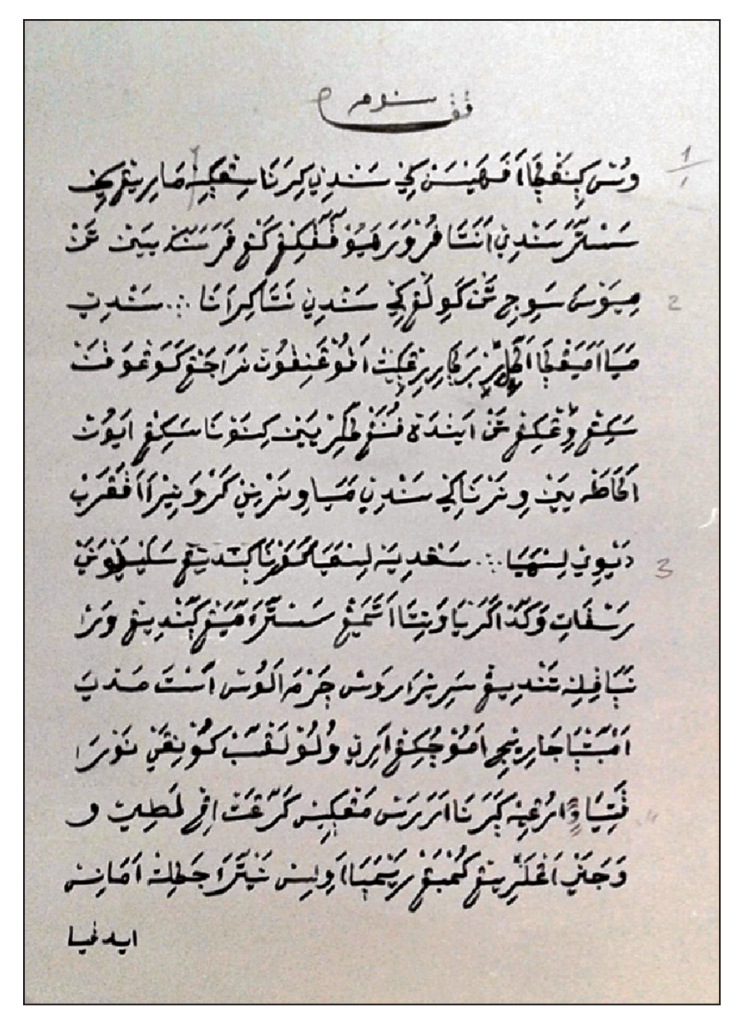

Naskah LOr. 7387. Sadjarah Banten.

\section{Hanacaraka}

Hanacaraka merupakan abjad Jawa yang berasal dari huruf Dewanagari, India. Abjad Jawa hanacaraka terdiri atas 20 huruf, yaitu ha na ca ra ka da ta sa wa la pa dha ja ya nya ma ga ba tha nga. Dalam perkembangan penulisannya, hanacaraka juga mengenal aksara murda (huruf Kapital), aksara swara (vokal), dan aksara rekaan (huruf khusus untuk menulis huruf asing, seperti kha, fa.).

6 Dalam buku Menyusuri Jejak Kesultanan Banten, Titik Pudjiastuti (2015: 29-31) menamakan naskah ini sebagai G.

7 Tembang macapat adalah puisi klasik Jawa yang membacanya per empat suku kata. Dalam tembang macapat, bait disebut pada dan bab disebut pupuh. Setiap pupuh mempunyai nama dan karakter yang berbeda, di antaranya adalah Dhandanggula, Sinom, Asmarandana, dan Pangkur. Setiap bait dari sebuah pupuh terdiri atas sejumlah baris (guru gatra), jumlah suku kata (guru wilangan) dan vokal akhir tiap baris (guru lagu) yang tertentu. Penjelasan lebih lanjut dapat dibaca dalam tulisan Karsono $\mathrm{H}$, Saputro (1992). 
Berdasarkan sumber tulis Banten, huruf hanacaraka tidak hanya digunakan untuk menulis teks sastra dalam bahasa Jawa tetapi juga untuk teks lain, seperti dokumen (arsip) dan surat dalam bahasa Melayu. Berikut ini adalah contoh penggunaan askara hanacaraka untuk menulis teks dalam bahasa Melayu dan Jawa.

Aksara hanacaraka yang digunakan untuk menulis teks bahasa Melayu ${ }^{8}$ ditemukan antara lain dalam surat Pangeran Aria Hupapatih untuk Jan Pieterzoon Coen yang ditulis pada 1619. Surat berukuran 19 x 15,5 cm itu, yang tersimpan di Algemeen Rijks-Archief (ARA) Denhaag, Belanda, menggunakan bahan naskah kertas eropa. Tebal naskah 1 lembar (recto-vrerso) dengan jumlah baris sehalaman 6 . Pada verso terdapat keterangan dalam bahasa Belanda: brieff van Oangeatn Aria. Ontvangen 26 Des, 1619. Isi surat: peringatan kepada kompeni, jika hendak berdagang dengan Banten harus membuat kesepakatan terlebih dahulu supaya adil dan tidak ada yang kecewa. Berikut petikan teksnya.

// surat Pangeran Arya Huapatih adhapun ka/pitan hendak badame biniyaga sarat urang ba/ dame biniyaga hendak sama betul/jangan adha kuciwa barangkali adha ku/ciwa bukan badhame namanya manakiti/juga namanya//

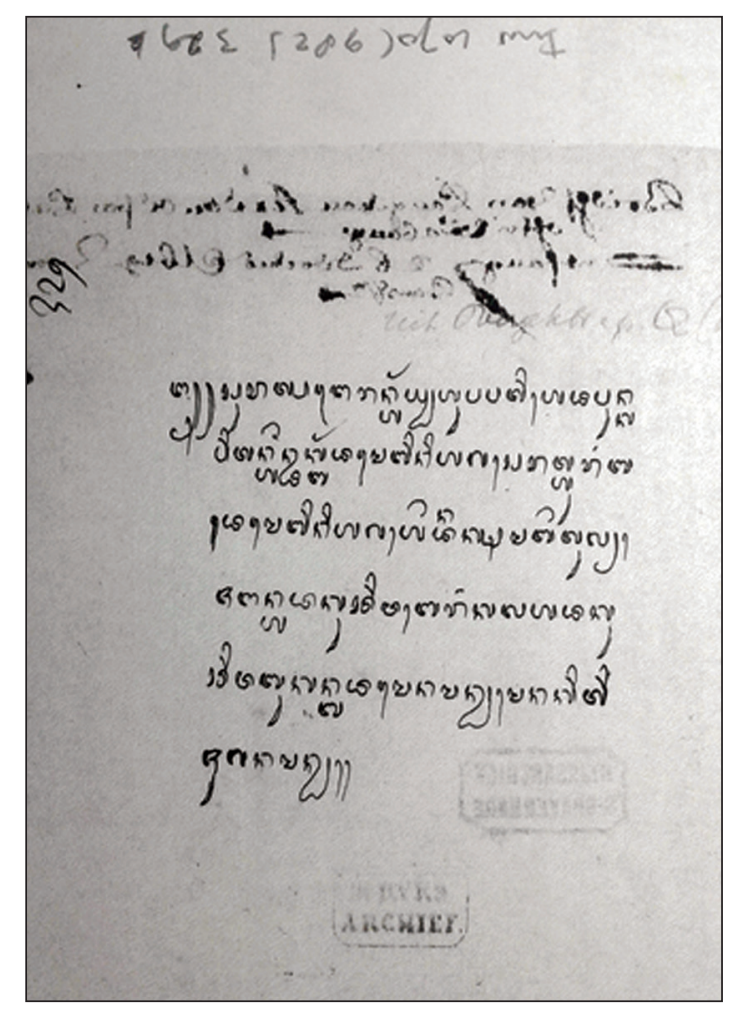

Surat Aria Hupapatih kepada Jan Pieterzoon Coen, 1619.

Sumber tulis Banten yang menggunakan aksara hanacaraka untuk teks berbahasa Jawa sangat banyak ditemukan. Salah satunya adalah surat Kiai Dinda Supati yang ditulis pada sekitar 1642. Surat itu tersimpan di Royal Library Copenhagen dalam bundel arsip Danish Chancery nomor RL B 244b III, Jav 19. Surat yang berukuran $33 \times 21,5 \mathrm{~cm}$ ini berisi teks sebanyak 7 baris sehalaman. Isi teks adalah kontrak perjanjian pengiriman barang di Banten. Berikut petikan teksnya

8 Surat beraksara hanacaraka berbahasa Melayu yang tersimpan di Algemeen Rijks-Archief (ARA) Denhaag, Belanda juga telah dibicarakan oleh Ricklefs (1976) dalam Bulletin of the Scholl of Oriental and African Studies University of London, Vol XXXIX. 
// penet// kyahi dinda supati haprajangji kalayan pun kumendur lan pun/ pétor hawade mariyos sahantukipun kyahi dinda supati bonten/hawade liyan samados nem sasi punika yen salamet bonten ke/nga ngawade liyan...

(//penekanan// Kyai Dinda Supati berjanji kepada Kumendur dan petor (bahwa) akan menjual merica sebanyak yang diperolehnya, Kyai Dinda Supati tidak akan menjual kepada yang lain dalam enam bulan ini jika (ingin) selamat tidak akan menjual pada yang lain ...)

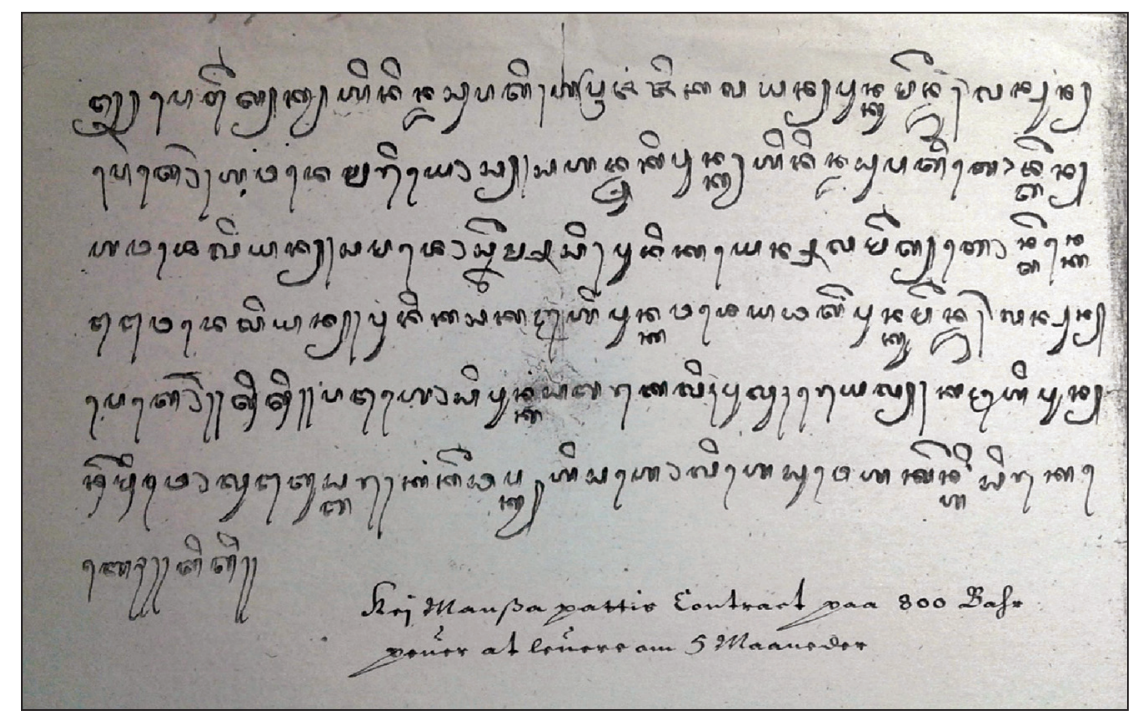

Surat Kiai Dinda Supati, koleksi Royal Library Copenhagen.

\section{Latin}

Tulisan Latin dibawa dan dikenalkan oleh bangsa Portugis pada abad ke-16, tetapi disebarluaskan ke berbagai daerah di Nusantara oleh orang Belanda dan Inggris. Menurut kebanyakan peneliti kebudayaan lama, tulisan Latin digunakan oleh bangsa Indonesia baru pada awal abad ke-20. Akan tetapi, dari penelitian yang telah dilakukan oleh Titik Pudjiastuti (2007) tulisan Latin ternyata telah digunakan sebagai sarana tulis oleh orang Banten sejak paruh kedua abad ke-17. Contohnya adalah surat Sultan Abu Nashar Abdul Qahar kepada Raja Inggris, Raja Charles II yang ditulis pada 1680.

Surat tersebut yang berukuran 35 × 22,5 cm tersimpan di Public Record Office, London dengan nomor kode arsip PRO CO 77/14, f.22. Tebal naskah 1 lembar (recto-verso) dengan jumlah baris per halaman 25, teksnya ditulis di atas kertas eropa. Isi teks menjelaskan kematian Kapten Moor White dan usaha Sultan Abu Nashar dalam menyelidiki kasus ini. Berikut adalah petikan teksnya

// Inee surat derri padadooca Serri Sultan Abdull Caharr Abdull Nassar yean parentacan negri Suraswan attaw Bantam dunan/gagania dungan acall yean lebbi bussar de toelong derri pada Alla taala/sampe capada Charles cadua yean de negri Engris Scotland France/... 


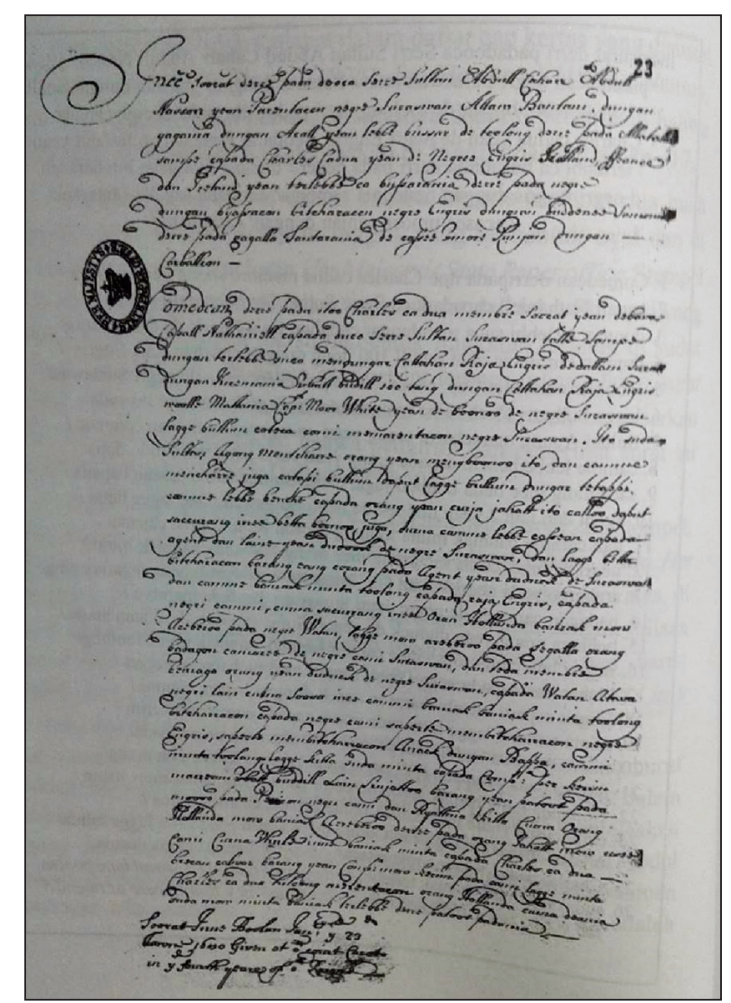

Surat Sultan Abu Nashar Abdul Qahar kepada Raja Inggris, Raja Charles II, 1680.

\section{Penutup}

Dari berbagai sumber yang membicarakan Banten, kita mengetahui bahwa wilayah itu ternyata telah lama "mendunia", bahkan jauh sebelum Kesultanan Banten berdiri. Lada menjadi daya tarik tersendiri bagi bangsa asing, khususnya bangsa Eropa, yang memerlukannya dalam kehidupan mereka. Kedatangan mereka ke Banten yang semula hanya sebagai konsumen lama kelamaan berubah menjadi keinginan untuk menguasai. Perpecahan intern yang terjadi pada tahun 1680-an dalam Kesultanan Banten menjadi penyebab hilangnya kemandirian Banten sebagai kerajaan yang berdaulat secara politis dan ekonomis sehingga berada di bawah tekanan dan kekuasaan kolonial Belanda. ${ }^{9}$ Keadaan itu tercermin dalam berbagai sumber tulis Banten yang sebagian kecil ditampilkan dalam contoh di atas.

Berdasarkan sumber tulis yang dikemukakan di atas, kita juga mengetahui bahwa aksara yang digunakan sebagai sarana tulis di Banten pada masa lalu ada lima, yaitu aksara Arab, Jawi, Pegon, Hanacaraka, dan Latin ditambah dengan dua variasi lain, yaitu aksara Pegon dan hanacaraka yang digunakan untuk menulis teks berbahasa Melayu. Jika sumber tulis itu dicermati secara lebih mendalam, kita dapat melihat bahwa aksara itu bukan saja berfungsi sebagai sarana tulis melainkan juga rangkaian hurufnya telah memuat banyak informasi penting tentang Banten. Dengan demikian, aksara itu dapat juga dikatakan telah berperan sebagai penyimpan informasi dari berbagai aktivitas yang terjadi di Banten.

9 Baca antara lain: Perdagangan di Kesultanan Banten (1552-1684) Kajian Arkeologi-Ekonomi, Heriyanti Ongkodharma Untoro, 1998 dan Menyusuri Jejak Kesultanan Banten, Titik Pudjiastuti, 2015, Jakarta: Wedatama Widyasastra. 


\section{Daftar Referensi}

Bruinessen, Martin van. 1995. 'Shari'a court, Tarekat and Pesantren: Religious Institution. Archipel 50.

Chamber-Loir. 1995. "Kerajaan Banten Sebelum Islam" makalah dalam Simposium Internasional: Kedudukan dan Peranan Banten dalam Perdagangan Internasional. Serang: Kerja Sama Puslitarkenas dan Pemda Tk. II Kabupaten Serang.

Chijs, J.A. van der. 1881. "Oud Bantam" dalam TBG No. 26.

Colombijn, F. 1989. "Foreign Influence on the State of Banten, 1956-1682". Dalam Indonesa Circle, November (50): 19-30.

Drewes, G.W.J.1995. "Short Notice on the Story of Haji Mangsur of Banten." Dalam Banten: Historie d'une région. Archipel 50.

Edel, Jan, 1938. Hikayat Hasanoedin. Disertasi, Universitas Utrecht.

Foster, William, 1943. John Company. London: John Lane.

Gallop, Annabel Teh dan Bernard Arps. 1991. Golden Letters Writing Tradition of Indonesia. London: The British Library, Jakarta: Yayasan Lontar.

De Graaf, H.J. dan Th. G. Th. Pigeaud, 1985. Kerajaan-Kerajaan Islam di Jawa Peralihan dari Majapahit ke Mataram. Jakarta: Grafiti Press.

Guillot Claude, dkk, 1990. The Sultanate of Banten. Jakarta: Gramedia.

Guy, John, 1997. Kings and Queens Book III 1603-1774. The Millenium Series. UK: Ticktock Publishing.

Heriyanti Ongkodharma Untoro. 1998. Perdagangan di Kesultanan Banten (1552-1684) Kajian ArkeologiEkonomi. Disertasi, Universitas Indonesia.

Heawood, Edward. 1950. Watermarks in paper in 18th-19th Century. Hilversum: The Paper Publications Society.

Hoesein Djajadingrat. 1983. Tinjauan Kritis tentang Sajarah Banten. Jakarta: Djambatan.

Ismail, Muhammad. 1983. Petunjuk Jalan dan Keterangan Bekas Kerajaan Kesultanan Banten. Serang: Saudara.

Jones, Russle. 1982. "The First Indonesia Mission to London." Dalam Indonesia Circle No. 28: 9-19.

Karsono H, Saputro. 1992. Tembang Macapat. Jakarta: Wedatama Wudya Sastra.

Lewis, M. 1985. A Handbook of Malay Scripts, London: Macmillan.

Meijer, J.J. 1890. "Bijdragen tot de Kennis van het Bantensch Dialect der Soendanische Taal " dalam BKI 39: 22-77.

Ota, Atsushi. 2006. Changes of Regime and Social Dynamics in West Java: Society, State and the Outer World of Banten 1750-1830. Leiden-Boston: Brill.

Pigeaud, Th. G. Th. 1967. Literature of Java. Catalogue Raesonne of Javanese Manuscripts in the Library of the University of Leiden and Other Public Collections in the Netherlands Vol. I. Den Haag: Nijhoff.

Ricklefs, M.C. 1976. "Banten and the Dutch in 1619: Six Early Pasar Malay letters." Dalam Bulletin of the Scholl of Oriental and African Studies University of London, Vol XXXIX: 128-36.

Talens, Johan. 1999. Een Feodale Samenleving in Koloniaal Vaarwater. Staatsvorming, Koloniale Expansie en Economische Onderontwikkeling in Banten, West Java (1600-1750). Hilversum: Verrloren.

Titik Pudjiastuti. 1999. "Sepucuk Surat dari Banten." Dalam Cerlang Budaya. Depok: LPUI. 1997. Perang, Dagang, dan Persahabatan. Surat-Surat Sultan Banten. Jakarta: Yayasan Obor Indonesia \& The Toyota Foundation. 2015. Menyusuri Jejak Kesultanan Banten. Jakarta: Wedatama Widya Sastra. 
Tjandrasasmita, Uka. 1967. Sultan Ageng Tirtayasa. Musuh Besar Kompeni. Jakarta: Yayasaan Kebudayaan Nusalarang.

Voorhoeve,P. 1975. "Two Malay Letters in The National Archives of Denmarak." Dalam BKI deel 131, s'Gravenhage: Martinus Nijhoff. 